九州大学学術情報リポジトリ

Kyushu University Institutional Repository

\title{
Feasibility of Paper-based Activated Carbon Fibers as Fried 0il Adsorbing Material
}

\section{LIN, Han Chien}

Laboratory of Environment Functional Materials, Department of Wood Based Materials and Design, College of Agriculture, National Chiayi University

YANG, Miao-Han

Master, Graduate Institute of Wood Based Materials and Design, College of Agriculture, National Chiayi University

FUJIM0T0, Noboru

Laboratory of Wood Material Technology, Division of Sustainable Bioresources Science, Department of Agro-environmental Sciences, Faculty of Agriculture, Kyushu University

https://doi.org/10.5109/2558903

出版情報: 九州大学大学院農学研究院紀要. 65 (1)，pp.113-122，2020-02. Faculty of Agriculture， Kyushu University

バージョン :

権利関係 : 


\title{
Feasibility of Paper-based Activated Carbon Fibers as Fried Oil Adsorbing Material
}

\author{
Han Chien LIN ${ }^{1 *}$, Miao-Han YANG ${ }^{2}$ and Noboru FUJIMOTO \\ Laboratory of Wood Material Technology, Division of Sustainable Bioresources Science, \\ Department of Agro-environmental Sciences, Faculty of Agriculture, \\ Kyushu University, Fukuoka 819-0395, Japan \\ (Received October 23, 2019 and accepted November 14, 2019)
}

\begin{abstract}
This study used corrugated cardboard (CC) as a precursor, and prepared the paper-based activated carbon fibers (PACFs) using steam activation, and evaluated the feasibility of using PACFs as fried oil adsorbing material. The yield of PACFs prepared under different activation conditions was $16.50-27.16 \%$, the iodine value was $205.77-586.05 \mathrm{mg} / \mathrm{g}$, and the methylene blue adsorption was $226.98-311.61 \mathrm{mg} / \mathrm{g}$. Under the BDDT classification, the PACFs belonged to Type II, characterized by a large amount of mesopores and hysteresis loop phenomenon. Based on the IUPAC classification, PACFs were the slit pores of Type H3. According to the physicochemical properties of frying oil after heating, the unsaturated fatty acid generated free radicals or performed polymerization to form polymers as the heating time increased. The color change and viscosity were increased. Fried oil generated free fatty acid due to heating and hydrolysis and then the acid value increased, while the smoke point decreased. Fried oil generated hydroperoxide and nonvolatile substance due to oxidation reaction. The peroxide value and thiobarbituric acid value were increased. In addition, the PACFs were ground into GPACFs (Granular PACFs) and DPACFs (Powdered PACFs), and different percent weight of them was used as the adsorbing material. The viscosity, acid value, peroxide value, and thiobarbituric acid value of the fried oil were influenced. The $5 \%$ impregnating was able to decrease the aforesaid items by $30.6,17.1,40.9$, and $71.3 \%$, respectively.
\end{abstract}

Key words: Corrugated Cardboard (CC), Paper-based Activated Carbon Fibers (PACFs), Fried Oil, Acid Value, Peroxide Value, Thiobarbituric Acid Value

\section{INTRODUCTION}

The Environmental Protection Administration of Taiwan (2018) indicates that Taiwan's average annual waste yield is about $3714541.67 \mathrm{t} / \mathrm{year}$, and waste paper is 1968408.33 t/year, which is about $53 \%$ of the total waste yield. Waste paper is treated to make recycled paper, and the usability is degraded as the fiber length is shortened or/and the strength is decreased. To enhance the reproducibility of waste paper, such as the carbon material with absorbability, the waste paper recycling is one of the reused methods (Ellis and Sedlachek, 1993). As activated carbon is a carboniferous material with high specific surface area and porosity, it contains lots of pores with good absorbability and is extensively used for gas/liquid phase adsorption. The fibrous structures of wood pulp and spent kraft pulp are composed of plant cellulose. While the wall pores of the wood fiber are carbonized and activated to prepare wood-based activated carbon fibers (WACFs) (Huanh et al., 2010; Lin et al., 2015a; Lin et al., 2015b), the pore structure and absorption remain (Asakura et al., 2004). WACFs is free of mutagenicity (Lin et al., 2014a; Lin et al., 2015a) according to the Ames test (Ames, 1975), and there is no adverse effect according to the results of 28-day

\footnotetext{
1 Laboratory of Environment Functional Materials, Department of Wood Based Materials and Design, College of Agriculture, National Chiayi University, Chiayi, Taiwan, ROC

2 Master, Graduate Institute of Wood Based Materials and Design, College of Agriculture, National Chiayi University, Chiayi, Taiwan, ROC

* Corresponding author (E-mail: alexhlin@mail.ncyu.edu.tw)
}

feeding toxicity test on animals (Lin et al., 2014b; Lin et al., 2015b).

Foods fried at high temperatures have special aroma and crispness, and because the cooking time is short, it is well accepted by common people. However, food fried at high temperatures performs hydrolysis, oxidation, polymerization, pyrolysis, and thermal polymerization to generate free fatty acid, alcohols, cyclic peroxide, dimer, and polymer (Choe and Min, 2006), which are toxic, and there are some of adverse effects on human health (Ziaiifar et al., 2008). Various countries have specified the required quality of fried oil. In terms of fried oil quality regulations in Taiwan, according to Letter Weishu-Shi-Tze-Di\#098461015 (2010), the F\&B services fried oil check management principle-The Food nutrient database from the Ministry of Health and Welfare, the smoke point lower than $170^{\circ} \mathrm{C}$, the fried oil has a deep color and rancid odor, the foam area exceeds one and half of the fryer, and the acid value exceeds $2.0 \mathrm{mgKOH} / \mathrm{g}$ oil. Moreover, the present adsorbents are mostly activated carbon, zeolite, silicate, bentonite, diatomite, and perlite powder (Paul et al., 1997). Lin et al. (1998) indicate that activated carbon, calcium silicate, and magnesium silicate can reduce free fatty acid, lighten the color of fried oil, and extend oil and fat oxidation stability for effectively slowing the deterioration of fried oil. Yates and Caldwell (1993) use activated carbon or magnesium silicate to remove oil soluble substance, which postpones the rancidity of oil and fat more effectively than diatomite. The Ministry of Health and Welfare (2010) indicates the range of use and limit of food additives and specification standards in Letter 
Shou-Shi-Tze-Di\#1001301966, meaning that, while synthetic magnesium silicate is approved as a food processing filter aid (below 2\%), the effects of synthetic magnesium silicate, diatomite, and perlite powder remain uncertain for human health.

Therefore, this study used corrugated cardboard (CC) to prepare paper-based activated carbon fibers (PACFs) to investigate the effect of fried oil adsorbing material. The CC was used as the precursor to prepare different PACFs under different steam activations of physical activation. The basic properties of PACF were investigated. Afterwards, soybean oil was heated for the fried oil test. PACFs of different percent weight and sizes were impregnated into the fried oil, and the physical analysis method was used to determine color change, smoke point, and viscosity. The chemical analysis method was used for the acid value, peroxide value, and thiobarbituric acid value. Rancimat oxidation induction time was used to determine oil and fat oxidation stability as well. The fried oil quality before and after impregnating was determined to evaluate the effect of the PACFs made of CC on adsorbing the fried oil.

\section{MATERIALS AND METHODS}

\section{Specimen and its basic properties}

\section{Precursor}

Corrugated cardboard (CC), the precursor, was obtained from C company after being cut with the dimension of $1 \times 1 \mathrm{~cm}$ (without printing), and then oven-dried at $105^{\circ} \mathrm{C}$.

\section{Oil specimen}

Soybean oil was purchased from Haibao powder store in Chiayi, Taiwan.

\section{Basic properties of $C C$}

1. Moisture content (MC): the MC of CC was measured by the Chinese National Standards (CNS) 1356 (2010) Method of Test for Determination of Moisture Content in Pulp, Paper and Board (Oven-drying Method). The air-dried MC of CC was measured.

2. Ash: According to the CNS 1356 (2008) Methed of Test for Residue Ash Content of Pulps, Paper and Board on Ignition at $525^{\circ} \mathrm{C}$. The ash content of CC was measured.

\section{Chemical composition analysis of CC}

The chemical composition analysis of CC were included the contents of holocellulose and lignin and ethanol-toluene extractives.

1. The holocellulose of the CC was measured according to the CNS 4713 (2005) Method of Test for Holocellulose Content of Pulpwood and Other Fibrous Materials. The formula for holocellulose (\%) $=$ (the absolute dried weight of holocellulose / the absolute dried weight of precursor) $\times 100$.

2. The lignin content of CC was tested by the CNS 2721 (2010) Method of Testing for Determination of AcidInsoluble Lignin in Pulp and the CNS 12108 (1987)
Method of Testing for Acid-Soluble Lignin (Klason lignin) in Wood and Pulp. The formula for acid-insoluble lignin $(\%)=$ (the absolute dried weight of lignin / the absolute dried weight of precursor) $\times 100$. The formula for acid-insoluble lignin (\%) is $(\mathrm{B} \times \mathrm{V} \times$ $100) /(1000 \times W)$, where $B$ is the concentration of acid-soluble lignin $(\mathrm{g} / \mathrm{L}) ; \mathrm{V}$ is the total volume of solution (mL), and $\mathrm{W}$ is the absolute dried weight of the specimen. Furthermore, $\mathrm{B}=(\mathrm{A} \times \mathrm{D}) / 110$ where $\mathrm{A}$ is the absorbance and $\mathrm{D}$ is the diluted fold. Lignin content $(\%)=$ acid-insoluble lignin + acid soluble lignin.

3. The ethanol-toluene extractives of $\mathrm{CC}$ were measured according to the CNS 4713 (2005) Method of Testing for Ethanol-Toluene Extractives in Wood. The formula for ethanol-toluene extractives (\%) = (the absolute dried weight of extractives / the absolute dried weight of precursor) $\times 100$.

\section{Evaluation of PACFs as Fried Oil Adsorbing Material}

Preparation of PACFs

The precursor, CC, was dried in an oven at $105^{\circ} \mathrm{C}$ for $24 \mathrm{~h}$. For the first step-carbonization, the resulting specimen was loaded in a crucible, which was placed inside an upright high-temperature activation furnace (inner diameter, $26 \mathrm{~cm}$; inner height, $40 \mathrm{~cm}$; Ch-1116, Taiwan) and was heated under a nitrogen $\left(\mathrm{N}_{2}\right.$ gas) flow rate of $200 \mathrm{~mL} / \mathrm{min}$ for carbonization at a rate of $10^{\circ} \mathrm{C} /$ min. $\mathrm{N}_{2}$ gas was added to make the container oxygen free. The carbonization temperature was set at 700, 750, 800 , and $850^{\circ} \mathrm{C}$. The second step-activation inserted the activation gas-steam, which was heated from deionized water with the flow rate set at 90 and $120 \mathrm{~mL} / \mathrm{h}$. The activation temperature was set at 700, 750, 800, and $850^{\circ} \mathrm{C}$ with activation duration of $60 \mathrm{~min}$. In the third step, the paper-based activated carbon fibers (PACFs) was cooled by $\mathrm{N}_{2}$ gas to a normal temperature for $4 \mathrm{~h}$ and taken out. The aforesaid preparation conditions refer to (Kim et al., 2001; Zhang et al., 2004; Amuda et al., 2007; Tseng et al., 2007; Aworn et al., 2008; Huang et al., 2010; Wu et al., 2010; Peng et al., 2012; Lin et al., 2014a and Lin et al., 2015a). The resulting PACFs code was an activation temperature-flow rate, such as: T700-90 for PACFs that was prepared with the carbonization temperature of $700^{\circ} \mathrm{C}$ with a flow rate of $90 \mathrm{~L} / \mathrm{h}$.

\section{Characterization of PACFs}

1. The yield of PACFs (based on a dry basis) was calculated using the following equation (Eq.): Yield (\%) = (the absolute dried weight of PACFs / the absolute dried weight of CC) $\times 100$.

2. The iodine value of PACFs was determined according to the Japanese Industrial Standard (JIS) K 1474 (1991) Test Methods for Activated Carbon. The formula for iodine adsorption capacity is: $\mathrm{I}=[(10-\mathrm{K} \times$ f) $\times 12.69 \times 5$ ] $/ \mathrm{M}$. The abbreviations for the formula are I: iodine adsorption capacity (mg/g); K: the volume of titrated sodium thiosulfate $(\mathrm{mL})$; $\mathrm{f}$ : the ratio of $0.1 \mathrm{~N}$ sodium thiosulfate to $0.1 \mathrm{~N}$ iodine solu- 
tion, and M: the weight of absolute dried PACFs (0.5 g).

3. The methylene blue adsorption value of PACFs (1 mg) was added to a $25 \mathrm{~mL}$ aqueous solution containing $1 \mathrm{~g} / \mathrm{L}$ of methylene blue solution and shaken at room temperature $\left(30^{\circ} \mathrm{C}\right)$. When the aqueous solution became colorless, methylene blue solution was repeatedly added to the flask to assure equilibrium adsorption of the MB. After filtration, the concentration of residual methylene blue solution was determined using a UV-vis spectrophotometer (CECIL, CE3041) at a wavelength of $664 \mathrm{~nm}$. (Wu et al., 2010)

4. The pore structure characteristics of PACFs were measured by nitrogen adsorption-desorption isotherms at $77 \mathrm{~K}$ using a Micromeretics ASAP2000, Accelerated Surface Area and Porosimetry System at a relative pressure (P/Po) ranging from $10-2$ to 1 . The BET specific surface area (SBET) was determined using the standard BET equation. ( $\mathrm{Hu}$ and Srinivasan, 1999)

\section{Preparation of different particle-like PACFs}

The PACFs with better yield, iodine value, and methylene blue solution were selected. The GPACFs (Granular PACFs, 8 mesh) and DPACFs (Powdered PACFs, 60 mesh) were prepared and absolutely dried for future use.

\section{Preparation of fried oil specimen}

$3 \mathrm{~L}$ soybean oil (as Blank) was heated at $180 \pm 10^{\circ} \mathrm{C}$ for $4 \mathrm{~h}$ per day for 5 consecutive days, $150 \mathrm{~g}$ of the fried oil specimen (as Control) was put in a conical flask after cooling every day, and sealed at $4^{\circ} \mathrm{C}$ for determining the physicochemical properties.

\section{Fried oil impregnating test}

The PACFs of different percent weight (1, 3, and $5 \%)$ and different particle sizes were impregnated into above fried oil specimens. The test procedures weredescribed, as follows.

1. $150 \mathrm{~g}$ specimen was put in a $250 \mathrm{~mL}$ beaker.

2. $1.5,4.5$, and $7.5 \mathrm{~g}$ PACFs were put in the beaker, and placed in shade for $24 \mathrm{~h}$.

3. The PACFs impregnated in the fried oil specimen were filtered by filter paper, and the filtered fried oil specimen was prepared for determining the physicochemical properties.

\section{Fried oil properties determination}

The fried oil heated at $180 \pm 10^{\circ} \mathrm{C}$ for $4,8,12,16$, and $20 \mathrm{~h}$ was the control group (Control), and the PACFs impregnated in the fried oil after different heating time were the test group. The analytical items included:

1. Physical analysis method

(1) Color change refers to the measuring method of AOCS Official Method Cc 13b-45 (2017).

(2) Smoke point refers to the measuring method of AOCS Official Method Cc 9a-48 (2017).
(3)Viscosity: $200 \mathrm{~mL}$ fried oil specimen was put in a $250 \mathrm{~mL}$ beaker and measured by viscosimeter (Brookfield DV-I + Viscometer).

2. Chemical analysis method

(1)Acid value was tested according to AOCS Official Method Cd 3d-63 - Acid Value (2017). Eq.: acid value $(\mathrm{mg} \mathrm{KOH} / \mathrm{g})=[(\mathrm{V} 1-\mathrm{V} 2) \times \mathrm{N} \times 56.11] / \mathrm{W}$

Where V1: KOH ethanol solution (mL) consumed by titration sample; V2: $\mathrm{KOH}$ ethanol solution (mL) consumed by titration blank test; $\mathrm{N}$ : $\mathrm{KOH}$ ethanol solution strength $(\mathrm{N})$; W: fried oil specimen weight (g)

(2)Peroxide value was tested according to AOCS Official Method Cd 8b-90 - Peroxide Value Acetic AcidIsooctane Method (2017). Eq.: peroxide value $=[(\mathrm{V} 1-\mathrm{V} 2) \times \mathrm{N} \times 1000] / \mathrm{W}$

Where V1: $\mathrm{Na}_{2} \mathrm{~S}_{2} \mathrm{O}_{3}$ solution (mL) consumed by titration sample; V2: $\mathrm{Na}_{2} \mathrm{~S}_{2} \mathrm{O}_{3}$ solution (mL) consumed by titration blank test; $\mathrm{N}: \mathrm{Na}_{2} \mathrm{~S}_{2} \mathrm{O}_{3}$ solution strength $(\mathrm{N})$; W: fried oil specimen weight (g)

(3) Thiobarbituric acid value was tested according to AOCS Official Method Cd 19-90 - 2-Thiobarbituric Acid Value (2017), Direct Method. Eq.: thiobarbituric acid value $=[50 \times(\mathrm{A}-\mathrm{B})] / \mathrm{m}$

Where 50: dilution factor; A: absorbance value of test; B: absorbance value of blank group; m: fried oil sample weight (mg)

(4)Oil and fat oxidation stability was determined by Rancimat methods referring to the AOCS Official Method 12b-92 - Oil Stability Index method (2017).

\section{Statistical analysis}

The test results are represented by a mean (standard deviation), and the test groups are compared by Duncan's Analysis. If the $\rho$ value is smaller than 0.05, meaning a significant difference among the test groups, it is represented by different superscript upper case letters.

\section{RESULTS AND DISCUSSION}

\section{Basic properties of $\mathrm{CC}$}

The air-dried moisture content of CC was $6.70 \%$, the ethanol-toluene extractives was $2.37 \%$, the holocellulose was $75.51 \%$, the lignin was $11.29 \%$, and the ash was $10.76 \%$. The additional adhesive for making CC is possibility with a higher inorganic content (Bivainis and Jankauskas, 2015).

\section{Characterization of PACFs}

Yield, iodine value and methylene blue adsorption value

As the organic substance was volatilized after the precursor was carbonized at high temperature, the yield of PACFs decreased as the activation temperature increased (Table 1). This is because the gasified carbon content increases, the tar is dissipated and then effectively removed at activation temperatures of 800 and $850^{\circ} \mathrm{C}$ (Teng and Hus, 1999). In addition, the yield decreases as the steam activation flow increases because 
Table 1. Yield, iodine value and methylene blue adsorption of paper-based activated carbon fibers with different activation conditions

\begin{tabular}{|c|c|c|c|}
\hline Specimen & Yield (\%) & Iodine value (mg/g) & $\begin{array}{c}\text { Methylene blue } \\
\text { adsorption value (mg/g) }\end{array}$ \\
\hline $\mathrm{T} 700-90^{1)}$ & $27.16(1.63)^{a 2)}$ & $205.77(11.11)^{\mathrm{d}}$ & $-{ }^{3)}$ \\
\hline T750-90 & $23.16(0.54)^{\mathrm{b}}$ & $329.86(10.75)^{c}$ & $240.28(3.89)^{\mathrm{b}}$ \\
\hline T800-90 & $19.50(0.68)^{\mathrm{c}}$ & $586.05(16.93)^{\mathrm{b}}$ & $247.37(1.80)^{\mathrm{a}}$ \\
\hline T850-90 & $18.38(1.16)^{\mathrm{c}}$ & $526.41(16.03)^{\mathrm{a}}$ & $245.85(1.13)^{\mathrm{ab}}$ \\
\hline T700-120 & $26.99(0.44)^{\mathrm{a}}$ & $288.63(30.27)^{\mathrm{b}}$ & - \\
\hline T750-120 & $22.23(0.42)^{\mathrm{b}}$ & $319.85(7.26)^{\mathrm{b}}$ & $230.69(2.56)^{\mathrm{b}}$ \\
\hline T800-120 & $17.52(0.44)^{c}$ & $545.89(61.20)^{\mathrm{a}}$ & $226.98(0.73)^{b}$ \\
\hline T850-120 & $16.50(0.60)^{\mathrm{d}}$ & $556.56(08.98)^{\mathrm{a}}$ & $311.61(15.06)^{\mathrm{a}}$ \\
\hline
\end{tabular}

1) T700-90: T (Activation temperature) -flow rat

${ }^{2)}$ Mean (standard deviation) with the different superscripts are significantly different $(\rho<0.05)$ by Duncan's multiple range tests

3) -: non detected

steam activation strongly erodes the precursor, and the surface oxidation (Okada et al., 2003; Asakura et al., 2004). The iodine value increased with activation temperature, and in the same activation duration the iodine adsorbance of PACFs increased with activation temperature. Aworn et al. (2008) reports that the steam increases with activation temperature, the activated carbon micropores are widened continuously in Stage 2 of physical activation, and adjacent micropores are lost by activation and disintegrate to form wider micropores and mesopores. Therefore, the results were showed that the pore volume was increased, leading to a higher methylene blue adsorption and lower yield.

\section{Porosity of PACFs}

The BET specific surface area of the PACFs prepared from CC at the activation temperature of $800^{\circ} \mathrm{C}$ and steam flow of $90 \mathrm{~mL} / \mathrm{h}$ was $191.45 \mathrm{~m}^{2} / \mathrm{g}$, the total pore volume was $0.15 \mathrm{~cm}^{3} / \mathrm{g}$, the microporosity was $25.7 \%$, the mean pore size was $3.16 \mathrm{~nm}$, the isotherm was classified according to BDDT classification (Gregg and Sing, 1982), and T800-90 was a Type II, meaning the pores were mostly mesopores (results not shown in
Table). In the adsorption process, the monolayer adsorption is formed first, and then multilayer adsorption is performed. Afterwards, there is a capillary condensation phenomenon in the pores, where the adsorption/desorption isotherm generates a hysteresis loop, and it is Type H3 according to International Union of Pure and Applied Chemistry classification, meaning the pores are slit type (Brunaver, 1943).

\section{Physicochemical properties of fried oil}

The peroxide and polymer resulted from the oxidation, hydrolysis, and isomerization of fried oil influences the color change, and increases the turbidity of the fried oil (Lin et al., 1998). After the soybean oil was heated for $4,8,12,16$, and $20 \mathrm{~h}$, its color gradually changed from golden yellow into reddish brown (Table 2). The red value ( $\mathrm{R}$ value) increased slightly, the yellow value (Y value) increased from 0.17 to 2.67, and the blue value (B value) unchanged.

The smoke point of frying oil is influenced by the oxidative pyrolysis product content of micromolecules, such as free fatty acid, where the free fatty acid is derived from the hydrolytic reaction, which increases

Table 2. Physicochemical properties of frying oil before/after heating

\begin{tabular}{|c|c|c|c|c|c|c|c|c|c|}
\hline \multirow{2}{*}{ Specimen } & \multirow{2}{*}{$\begin{array}{l}\text { Heating } \\
\text { time } \\
\text { (h) }\end{array}$} & \multicolumn{2}{|c|}{ Color change } & \multirow{2}{*}{$\begin{array}{l}\text { Smoke point } \\
\left({ }^{\circ} \mathrm{C}\right)\end{array}$} & \multirow{2}{*}{$\begin{array}{l}\text { Viscosity } \\
\text { (cP) }\end{array}$} & \multirow{2}{*}{$\begin{array}{l}\text { Acid value } \\
\text { (mg KOH/g } \\
\text { oil) }\end{array}$} & \multirow{2}{*}{$\begin{array}{c}\text { Peroxide } \\
\text { value } \\
\text { (meq/kg oil) }\end{array}$} & \multirow{2}{*}{$\begin{array}{c}\text { Thiobarbituric } \\
\text { acid value } \\
\text { (mg/kg oil) }\end{array}$} & \multirow{2}{*}{$\begin{array}{l}\mathrm{OSI}^{4)} \\
(\mathrm{h})\end{array}$} \\
\hline & & $\mathrm{R}$ value $^{3)}$ & Y value & & & & & & \\
\hline Blank $^{1)}$ & 0 & $0.00(0.00)^{5)}$ & $0.17(0.05)^{c}$ & $237.0(4.57)^{\mathrm{a}}$ & $51.40(1.81)^{c}$ & $0.11(0.00)^{d}$ & $0.00(0.00)^{c}$ & $0.154(0.02)^{b}$ & $7.33(0.24)^{\mathrm{a}}$ \\
\hline \multirow{5}{*}{ Control $^{2)}$} & 4 & $0.00(0.00)$ & $0.50(0.05)^{c}$ & $229.3(0.00)^{\mathrm{ab}}$ & $53.73(3.21)^{\mathrm{c}}$ & $0.15(0.03)^{\mathrm{d}}$ & $1.33(0.11)^{\mathrm{c}}$ & $0.156(0.05)^{\mathrm{b}}$ & $5.31(0.37)^{\mathrm{b}}$ \\
\hline & 8 & $0.00(0.00)$ & $0.63(0.05)^{c}$ & $227.3(2.46)^{\mathrm{b}}$ & $58.33(5.22)^{\mathrm{c}}$ & $0.24(0.03)^{\mathrm{c}}$ & $1.79(0.17)^{\mathrm{c}}$ & $0.191(0.06)^{b}$ & $4.23(0.09)^{\mathrm{c}}$ \\
\hline & 12 & $0.00(0.00)$ & $0.80(0.00)^{\mathrm{bc}}$ & $221.5(5.92)^{b}$ & $66.57(5.21)^{\mathrm{bc}}$ & $0.26(0.03)^{c}$ & $4.56(1.46)^{b}$ & $0.196(0.05)^{b}$ & $3.53(0.41)^{d}$ \\
\hline & 16 & $0.00(0.00)$ & $1.30(0.50)^{\mathrm{b}}$ & $209.4(4.41)^{c}$ & $80.90(3.91)^{b}$ & $0.33(0.00)^{b}$ & $5.31(1.03)^{\mathrm{b}}$ & $0.234(0.05)^{b}$ & $3.46(0.25)^{\text {de }}$ \\
\hline & 20 & $0.20(0.00)$ & $2.67(0.47)^{\mathrm{a}}$ & $204.7(2.82)^{c}$ & $121.67(14.09)^{\mathrm{a}}$ & $0.41(0.03)^{\mathrm{a}}$ & $13.43(0.97)^{\mathrm{a}}$ & $0.682(0.07)^{a}$ & $2.91(0.00)^{\mathrm{e}}$ \\
\hline
\end{tabular}

\footnotetext{
1) Soybean oil without heating (PACFs)

${ }^{3)} \mathrm{R}$ value: Red value; Y value: Yellow value; $B$ value: Blue value (non detected)

4) OSI: Oil Stability Index

5) See Table $1^{2)}$
}

2) Control (C): The fried oil heated at $180 \pm 10^{\circ} \mathrm{C}$ for $4,8,12,16$, and $20 \mathrm{~h}$ without impregnating paper-based activated carbon fibers 
with frying time, thus, the oil smoke yield increases as the smoke point decreases. The fried oil is pyrolyzed into a micromolecular substance by oxidation, which reduces the smoke point (Bracco et al., 1981). Sun et al. (2007) indicate that oil smoke contains complex chemical substances, including various compounds, such as volatile substance and Polycyclic Aromatic Hydrocarbons (PAHs), thus, long-term exposure increases the risk of lung cancer. The results from Table 2 were also indicated that the smoke point of heated frying oil decreased slowly, and the temperature decreased rapidly after 16 and $20 \mathrm{~h}$. The smoke point was $237.0^{\circ} \mathrm{C}$ before the frying oil was heated, which was decreased by $13 \%$ to $204.7^{\circ} \mathrm{C}$ after $20 \mathrm{~h}$. When frying oil is heated, the high temperature pyrolysis and oxidation generate many free radicals, the polymerization is likely to form high polymer, and the viscosity is increased with heating temperature (Al-Harbi and Al-Kabtani, 1993). The viscosity of frying oil increased gradually with heating time, and after $20 \mathrm{~h}$ heating, the viscosity of frying oil was increased from 53.73 to $121.67 \mathrm{cP}$ (Table 2).

After the fatty acid of frying oil is oxidized and the triglyceride oil is hydrolyzed, the free fatty acid is formed, which is an important index for determining frying oil. The longer the frying time, the more free fatty acids are generated, and the higher the acid value (Frega et al., 1999). After $20 \mathrm{~h}$ heating of frying oil at $180 \pm 10^{\circ} \mathrm{C}$, the acid value increased from $0.11 \mathrm{mg}$ $\mathrm{KOH} / \mathrm{g}$ oil to $0.41 \mathrm{mg} \mathrm{KOH} / \mathrm{g}$ oil. After $8,12,16$, and $20 \mathrm{~h}$ of heating, the acid value exceeded the CNS 749 acid value standard (2015) (0.15 mg $\mathrm{KOH} / \mathrm{g}$ oil) for edible soybean oil, but the results were less than $2.0 \mathrm{mg} \mathrm{KOH/g}$ oil, according to Letter Wei-shu-Shi-Tze-Di\#098461015 (2009), the Frying oil replacement standard from the Ministry of Health and Welfare.

The peroxide value is used to determine the peroxide content in frying oil, as the unsaturated fatty acid of frying oil is combined with oxygen, which forms hydroperoxide due to the autoxidation reaction in the frying process. The hydroperoxide is an unstable material, which is rapidly generated in the initial stage of frying. The peroxide value; therefore, is an index only applicable to determining deterioration in the initial stage of the oxidation of frying oil. The split product derived from heated frying oil can induce intestinal mucosa dysfunction, large intestine cell proliferation, and hepatomegaly, which are harmful to the human body (Fritsch, 1981; Stevenson et al., 1984). It was also known that the peroxide value of frying oil increased with heating time (Table 2), and exceeded the CNS 749 peroxide value standard (2015) (10 meq/g oil) of edible soybean oil after $20 \mathrm{~h}$.

The thiobarbituric acid value is used to determine the resultant malondialdehyde of frying oil after oxidation, meaning it is an index for evaluating oil rancidity. The thiobarbituric acid value increases when the soybean oil is heated, which is due to the malondialdehyde generated by C18:3 oxidation (Buck, 1981; Huang et al., 1981; Keijbets et al., 1985). According to Table 2, the thiobarbituric acid value was $0.154 \mathrm{mg} / \mathrm{kg}$ oil before the frying oil was heated, and this value gradually increased when the oil was heated at $180 \pm 10^{\circ} \mathrm{C}$ for different periods of time, and was $0.682 \mathrm{mg} / \mathrm{kg}$ of oil after $20 \mathrm{~h}$ of heating.

The electrical conductivity of a frying oil split product is determined by using the Rancimat method to evaluate the oil and fat oxidation stability (Jain et al., 2005). Läubliand Bruttel (1986) indicates that the induction time of the Rancimat method is mainly influenced by the content of volatile oxide; the longer the induction time, the higher the oxidation stability (Oil Stability Index, OSI). The SOI of induction time of unheated soybean oil was $7.33 \mathrm{~h}$, it was $2.91 \mathrm{~h}$ after $20 \mathrm{~h}$ of heating, and the induction time was shortened, and the volatile oxide content in the frying oil increased gradually during different heating time, and the induction time of frying oil gradually shortened, meaning the SOI decreased (Table 2).

After $20 \mathrm{~h}$ of heating, the color change, viscosity, acid value, and peroxide value of frying oil was increased with heating time; whereas, the smoke point and oil and fat oxidation stability decreased as the heating time extends. The follow experimental was the PACFs of different sizes (8 and 60 mesh) and different percent weight $(1,3$, and 5\%), which were impregnated in frying oil heated for different periods of time, in order to evaluate the quality change before and after heating.

\section{Evaluation of fried oil by PACFs impregnating Color change}

When the frying oil is heated, the unsaturated fatty acid in the oil and fat structure generates free radicals, or polymerization occurs, the frying oil is darkened, the molecular weight is increased, and the viscosity is increased. Moreover, there are even carcinogenic cyclics if the oil is overheated (Stevenson et al., 1984; Gutierrez et al., 1988; Lumley, 1988). The Y value and $\mathrm{R}$ value of different frying oils were increased after different heating time. The PACFs impregnating treatment was able to decrease the $\mathrm{Y}$ value of frying oils heated for different time (results not shown in Table). It may be because the PACFs have mesopores, which can adsorb the peroxides and polymers resulted from oxidation, hydrolysis, and isomerization. The 5\% DPACFs and GPACFs impregnated in the frying oil heated at $180 \pm 10^{\circ} \mathrm{C}$ for 8 and $12 \mathrm{~h}$ had better results.

\section{Smoke point}

The smoke point is one of the indexes for testing the freshness of frying oil, meaning the temperature when thin smoke begins to occur when frying oil is heated. Frying oil generates volatile or nonvolatile compounds due to hydrolysis, oxidation, and polymerization, and most of these volatile compounds drift into the atmosphere, such as aldehydes, ketones, and short chain alkane and olefin, and the free fatty acids are increased. When the oil is heated and oxidized to generate cyclic fatty acid or combined with oxidation products into dimer and polymer, the frying oil viscosity is increased, the colloid is generated, and the heat transfer is 
reduced, thus, the smoke point drops (Choe and Min, 2007). Sun et al. (2007) indicate that frying oil heated at high temperatures generates lots of oil smoke, and long-term exposure can induce inflammatory reaction, higher oxidative stress, and cell proliferation; moreover, the oil smoke contains complex compounds, most of which are toxic, and correlated with pulmonary carcinogenesis.

The DPACFs and GPACFs of different percent weight impregnated in frying oils heated at $180 \pm 10^{\circ} \mathrm{C}$ for 4, 8, 12, 16 and $20 \mathrm{~h}$, and D5, G3 and G5 were able to increase the smoke point (results not shown in Table). As the activated carbon surface contains a basic functional group that performs neutralization between acid and a base with free fatty acids, the smoke point can be increased by reducing the free fatty acids (Proctor and Gnanasambandam, 1997). This may be because the pores after the PACFs are activated can adsorb the dimer and polymer in the frying oil, meaning the smoke point increases and the probability of lung cancer is reduced.

\section{Viscosity}

The viscosity of frying oil is influenced by the molecular length of fatty acid, meaning viscosity increases with the average length of fatty acid. In long-term heating of frying oil, the unsaturated fatty acid in the lipid structure performs polymerization, which generates high polymers, and viscosity is increased. As heat transfer is reduced as viscosity increases, the smoke point drops, which generates gases harmful to the human body (Sun et al., 2007).

The viscosity changes of PACFs of different sizes and percent weight impregnated in frying oils heated for different times are shown in Table 3. The viscosity of frying oil increased with heating time. This is because the soybean oil contains a lot of polyunsaturated fatty acids, and there is polymerization when it is heated at high temperature. The viscosity decreases after impregnating treatment with different PACFs, which may be because the mesopores in the PACFs after steam activation can adsorb the polymers in the frying oil, such as the results of methylene blue adsorption obtained (Table 1). The oil heated for $12 \mathrm{~h}$ and treated with 3 and $5 \%$ GPACFs, as well as that heated for $20 \mathrm{~h}$ with all PACFs, were better.

\section{Acid value}

Frying oil is hydrolyzed due to water content and heating action. The fatty acids in triglyceride oil are hydrolyzed to form free fatty acids. The longer the heating time, the more free fatty acids are formed, and the higher the acid value (Stevenson et al., 1984). Bennion and Hanning (1956) indicate that, the higher the free fatty acid content in oil, the lower the smoke point, the more toxic oil smoke is generated, and the greater the probability of lung cancer. According to Table 4, the acid value of frying oil increased significantly with heating time. It has reached the CNS 749 acid value standard of edible soybean oil (2015) (0.15 mgKOH/g) after $4 \mathrm{~h}$ heating. However, It is lower than the $2.0 \mathrm{mg} \mathrm{KOH} / \mathrm{g}$ of frying oil (Ministry of Health and Welfare, 2009), meaning that because it may no adequate water for hydrolytic reaction, the free fatty acids are formed slowly.

The acid value of frying oil heated for $8 \mathrm{~h}$ was $0.24 \mathrm{mg} \mathrm{KOH} / \mathrm{g}$ oil. The acid values of that treated with 1,3 , and 5\% DPACFs impregnating were $0.18,0.15$, and $0.19 \mathrm{mg} \mathrm{KOH} / \mathrm{g}$ oil, respectively; the acid values treated with 1, 3, and 5\% GPACFs impregnating decreased to $0.18,0.15$, and $0.20 \mathrm{mg} \mathrm{KOH} / \mathrm{g}$ oil, respectively, while the acid value decreased to $37.5 \%$ after D3 and G3 impregnate treating. The PACFs were impregnated in frying oil heated for $12 \mathrm{~h}$, the acid value of oil treated with D1, D3, and different percent weight of GPACFs decreased to 0.16-0.19 $\mathrm{mg} \mathrm{KOH/g}$ oil, while that of D1, D3, G3, and G5

Table 3. Viscosity of different frying oil before/after impregnated with different particle size and percent weight of paper-based activated carbon fibers

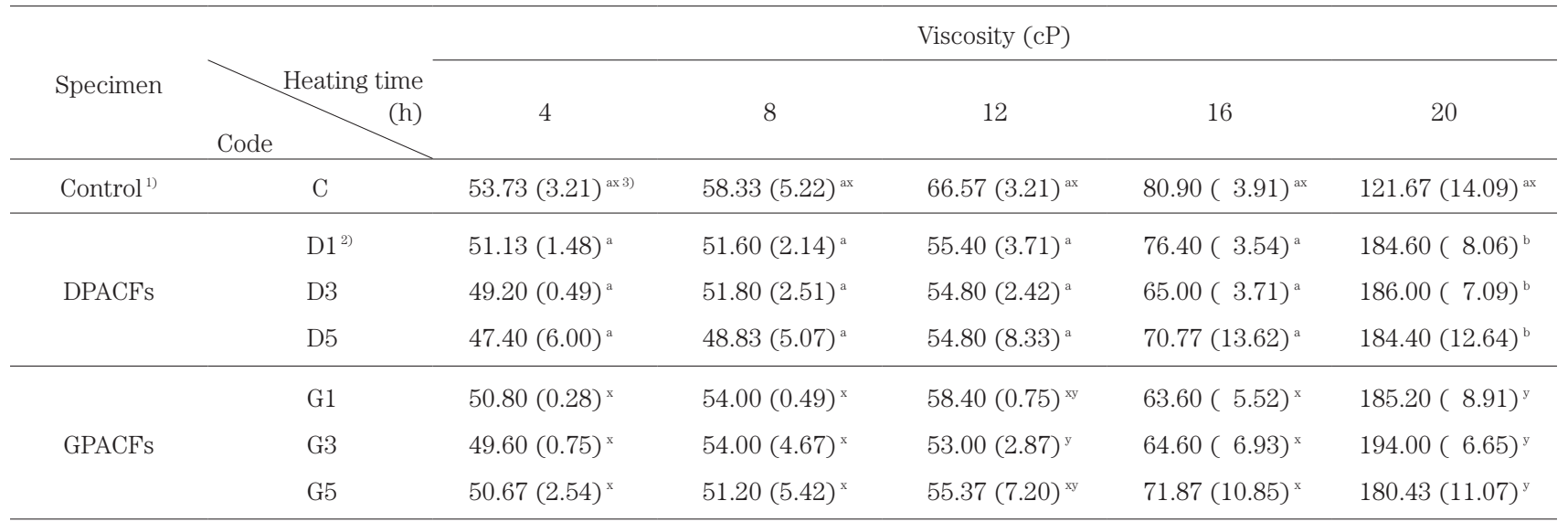

\footnotetext{
${ }^{1)}$ See Table $2^{2)}$

${ }^{2)}$ Specimen code: D1: 1\% percent weight of Granular PACFs; DACFs; G1: 1\% percent weight of Powdered PACFs

${ }^{3)}$ Mean (standard deviation) with the different superscripts are significantly different $(\rho<0.05)$ by Duncan's multiple range tests between different particle size of DPACFs and GPACFs
} 
Table 4. Acid value of different frying oil before/after impregnated with different particle size and percent weight of paper-based activated carbon fibers

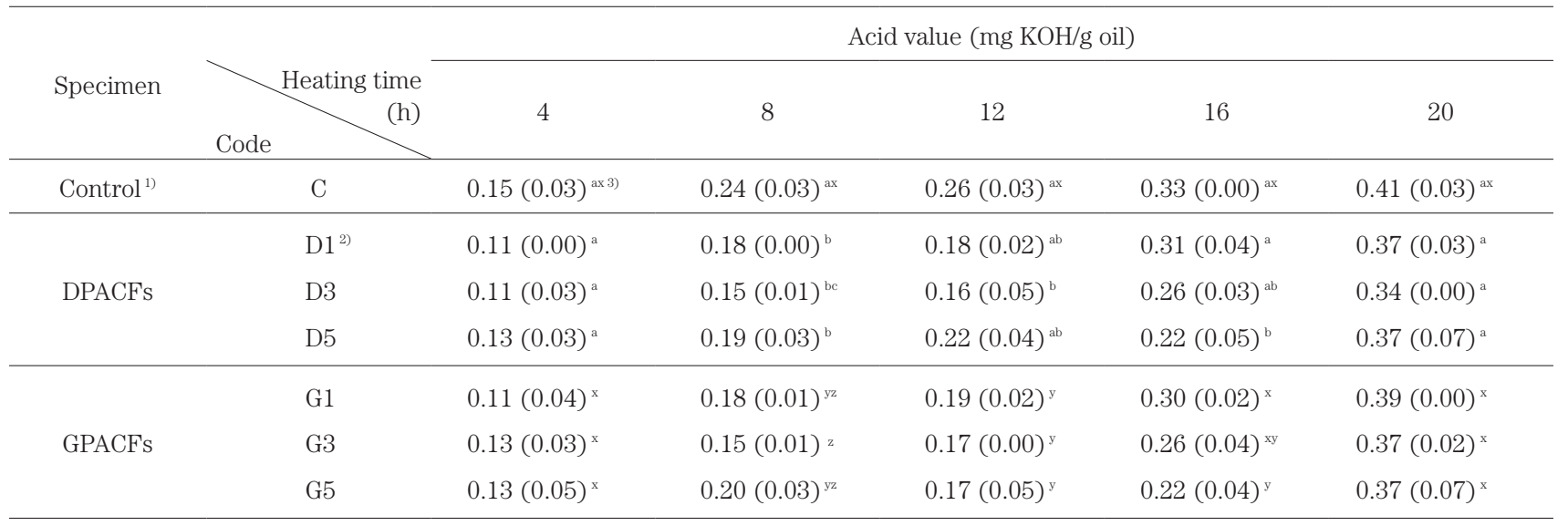

1), 2), 3) See Table 3

is $30.8-38.5 \%$.

The PACFs were impregnated in frying oil heated for $16 \mathrm{~h}$, the acid values of the oils treated with 5\% DPACFs were reduced by $33.3 \%$, to $0.22 \mathrm{mg} \mathrm{KOH} / \mathrm{g}$ oil, respectively. The acid value of frying oil heated for $20 \mathrm{~h}$ was $0.41 \mathrm{mg} \mathrm{KOH} / \mathrm{g}$ oil. After DPACFs impregnating of different percent weight, the acid values were $0.37,0.34$, and $0.37 \mathrm{mg} \mathrm{KOH} / \mathrm{g}$ oil, respectively, meaning all of them were decreased, while that of 3\%DPACFs was $17.1 \%$, and the acid value of frying oil treated with GPACFs impregnating was $0.37-0.39 \mathrm{mg} \mathrm{KOH} / \mathrm{g}$ oil, which was better than that without impregnating. Proctor and Gnanasambandam (1997) indicate that the basic functional group on the activated carbon surface performs acid-base action with free fatty acid, meaning the acid value of frying oil can be reduced.

\section{Peroxide value}

The peroxide value is one of the common indices for judging the degree of oxidation of oil and fat, and for determining the content of hydroperoxide generated in the initial stage of the oxidation of oil and fat.
Hydroperoxide is colorless and tasteless, and it is likely to be oxidized to reoxide (Iqbal and Bhanger, 2007). According to Table 5, the peroxide value of frying oil (Control) increased from $0.00 \mathrm{meg} / \mathrm{kg}$ oil to $13.43 \mathrm{meg} / \mathrm{kg}$ oil with heating time, and that of frying oil heated for $20 \mathrm{~h}$ exceeded the CNS 749 peroxide value standard of $10 \mathrm{meg} / \mathrm{kg}$ of edible soybean oil. The peroxide value of frying oil is increased when the high temperature and oxygen in the air induce autoxidation, thermal polymerization, and hydrolysis of fatty acids (Chugh and Dhawan, 2014). The hydroperoxide is likely to induce intestinal mucosa dysfunction and abnormal proliferation of intestine cells, which is likely to be split into peroxide, thus, damaging different cells and contributing to cell aging or death, as well as other gastrointestinal dysfunctions, such as hepatomegaly, angiopathy, diarrhea, and maldigestion (Boatella-Riera et al., 2000).

When PACFs were impregnated in frying oil heated for $4 \mathrm{~h}$, the peroxide value decreased from $1.33 \mathrm{meg} / \mathrm{kg}$ oil to $0.92-1.32 \mathrm{meg} / \mathrm{kg}$ oil, and the D5, G3, and G5 had the better sink rate of $25.6-30.8 \%$ (Table 5). When DPACFs and DPACFs were impregnated in frying oil

Table 5. Peroxide value of different frying oil before/after impregnated with different particle size and percent weight of paper-based activated carbon fibers

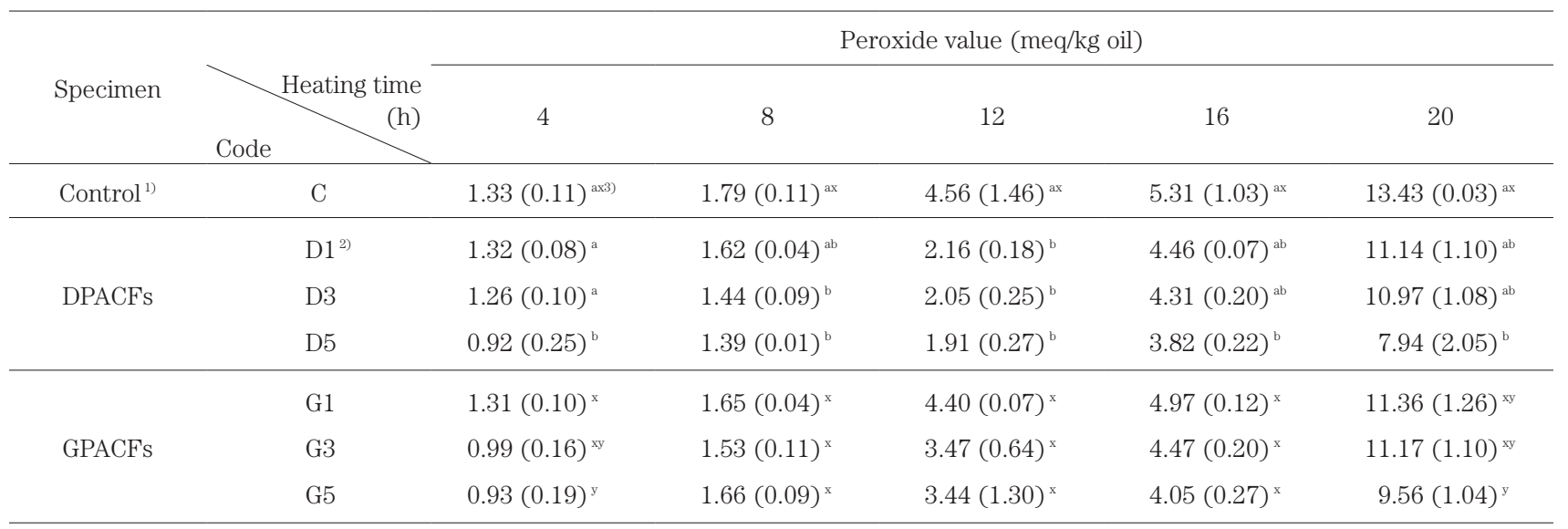

1), 2), 3) See Table 3 
heated for $8 \mathrm{~h}$, the D3, D5, and G3 had better effect, and the peroxide value decreased from $1.79 \mathrm{meg} / \mathrm{kg}$ oil to $1.44,1.39$, and $1.53 \mathrm{meg} / \mathrm{kg}$ oil, respectively. The peroxide value of frying oil heated for $12 \mathrm{~h}$ was $4.56 \mathrm{meg} / \mathrm{kg}$ oil, while that of 1,3, and 5\% DPACFs was 52.0, 55.0, and $58.1 \mathrm{meg} / \mathrm{kg}$ oil, respectively, which was reduced by $52.0-58.1 \%$. The peroxide value of $5 \%$ of DPACFs and GPACFs after $16 \mathrm{~h}$ heating decreased to 3.82 and $4.05 \mathrm{meg} / \mathrm{kg}$ oil, respectively. The peroxide value after $20 \mathrm{~h}$ heating increased to $13.43 \mathrm{meg} / \mathrm{kg}$ oil, but decreased after impregnating different percent weight of PACFs.

The peroxide values were able to be lower than the CNS 749 peroxide value standard (10 meg/kg oil) (2015) of edible soybean oil after D5 and G5 impregnating treatment, which were reduced by 40.9 and $28.8 \%$, respectively (Figure 1). Boki et al. (1991) indicate that with a large pore volume the BET specific surface area and functional group on the surface of the activated carbon can effectively adsorb hydroperoxide, and then reduce the peroxide value of fried oil.

\section{Thiobarbituric acid value}

The thiobarbituric acid value is a common index for determining the nonvolatile product malondialdehyde in the late oxidation stage of oil and fat, which is the oxidation product derived from the oxidation reaction of three unsaturated fatty acids above the double bond (Kanner et al., 2012). Del Rio et al. (2005) indicate that malondialdehyde has mutagenicity and carcinogenicity, and can cause cardiovascular diseases, such as cardiovascular tissue hardening. Malondialdehyde is likely to react with the basic group of nucleic acid, and this basic group combination can cause oxidative damage to cells, influence the physiological function of nucleic acid, and even disturb DNA to initiate hereditary disease (Marnett, 1999). The thiobarbituric acid value of unheated frying oil was $0.154 \mathrm{mg} / \mathrm{kg}$ oil, which increased to $0.682 \mathrm{mg} / \mathrm{kg}$ oil after $20 \mathrm{~h}$ heating at $180 \pm 10^{\circ} \mathrm{C}$. The thiobarbituric acid value of frying oil heated for different periods of time increased with heating time (Table 6). As activated carbon has better porosity, pore volume, BET specific

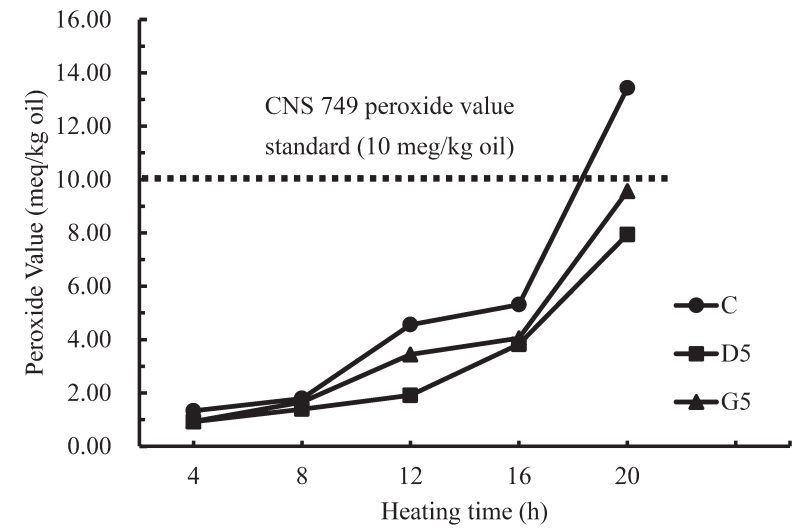

Fig. 1. Peroxide value of different frying oil before/after impregnated with different particle size and percent weight of paper-based activated carbon fibers.

Legends: C: The fried oil heated at $180 \pm 10^{\circ} \mathrm{C}$ for $20 \mathrm{~h}$ without impregnating PACFs

D5: $5 \%$ percent weight of Powdered PACFs impregnating with fried oil for $20 \mathrm{~h}$

G5: $5 \%$ percent weight of Granular PACFs impregnating with fried oil for $20 \mathrm{~h}$

surface area, and functional groups on its surface, it can effectively adsorb the organic compounds decomposed by hydroperoxide, such as aldehyde, ketone, alcohol, and acid products, in order to reduce the thiobarbituric acid value (Boki et al., 1991). The thiobarbituric acid values of frying oils treated with different percent weight of PACFs were reduced; frying oil heated for $16 \mathrm{~h}$ and treated with 5\% DPACFs and GPACFs, as well as that heated for $20 \mathrm{~h}$ and treated with PACFs, had better thiobarbituric acid values.

\section{CONCLUSIONS}

The study evaluated the feasibility of using PACFs made of CC as the adsorbing material for heated soybean oil. The PACFs yield was $16.50-27.16 \%$, the iodine value was 205.77-586.05 mg/g, and the methylene blue adsorp-

Table 6. Thiobarbituric acid value of different frying oil before/after impregnated with different particle size and percent weight of paperbased activated carbon fibers

\begin{tabular}{|c|c|c|c|c|c|c|}
\hline \multirow{2}{*}{ Specimen } & & \multicolumn{5}{|c|}{ Thiobarbituric acid value (mg/kg oil) } \\
\hline & $(\mathrm{h})$ & 4 & 8 & 12 & 16 & 20 \\
\hline Control $^{1)}$ & $\mathrm{C}$ & $0.156(0.05)^{a 3)}$ & $0.191(0.06)^{\mathrm{a}}$ & $0.196(0.05)^{\mathrm{a}}$ & $0.234(0.05)^{\mathrm{a}}$ & $0.682(0.07)^{\mathrm{aA}}$ \\
\hline \multirow{3}{*}{ DPACFs } & $\mathrm{D} 1^{2)}$ & $0.146(0.01)^{\mathrm{a}}$ & $0.175(0.01)^{a}$ & $0.177(0.01)^{\mathrm{a}}$ & $0.221(0.01)^{\mathrm{a}}$ & $0.228(0.01)^{\mathrm{a}}$ \\
\hline & D3 & $0.136(0.04)^{\mathrm{a}}$ & $0.172(0.03)^{\mathrm{a}}$ & $0.174(0.01)^{\mathrm{a}}$ & $0.208(0.02)^{\mathrm{ab}}$ & $0.219(0.02)^{\mathrm{ab}}$ \\
\hline & D5 & $0.133(0.04)^{\mathrm{a}}$ & $0.164(0.04)^{\mathrm{a}}$ & $0.171(0.02)^{\mathrm{a}}$ & $0.182(0.01)^{b}$ & $0.196(0.01)^{\mathrm{b}}$ \\
\hline \multirow{3}{*}{ GPACFs } & G1 & $0.146(0.03)^{x}$ & $0.176(0.01)^{x}$ & $0.181(0.01)^{\mathrm{x}}$ & $0.223(0.02)^{\mathrm{x}}$ & $0.237(0.01)^{\mathrm{x}}$ \\
\hline & G3 & $0.144(0.00)^{x}$ & $0.175(0.01)^{\mathrm{x}}$ & $0.179(0.00)^{x}$ & $0.212(0.01)^{\mathrm{xy}}$ & $0.227(0.00)^{x}$ \\
\hline & G5 & $0.134(0.02)^{\mathrm{x}}$ & $0.166(0.03)^{\mathrm{x}}$ & $0.176(0.01)^{\mathrm{x}}$ & $0.188(0.01)^{y}$ & $0.204(0.01)^{y}$ \\
\hline
\end{tabular}

1),2),3) See Table 3 
tion was 230.69-311.61 mg/g. The PACFs belonged to Type II, as characterized by a large amount of mesopores and hysteresis loop phenomenon. It was also slit type pore of Type H3. The color change, viscosity, acid value, peroxide value, and thiobarbituric acid value of soybean oil were increased with heating time, while the smoke point and oil and fat oxidation stability were decreased as the heating time extended. The 1, 3, and 5\% DPACFs and GPACFs were impregnated in oil heated for different time, and the smoke point and viscosity were decreased. The oils heated for $12 \mathrm{~h}$ and treated with 3 and $5 \%$ GPACFs, and oils heated for $20 \mathrm{~h}$ and treated with all PACFs, had better results. The acid values of oil heateded for different time decreased after impregnating treatment with different percent weight of DPACFs and GPACFs. Different PACFs decreased the peroxide value of oil heated for different time. The oil heated for $12 \mathrm{~h}$ and treated with different DPACFs had better effect. The peroxide values of oils heated for $20 \mathrm{~h}$ and treated with 5\% DPACFs and GPACFs were greatly decreased by 40 and $28 \%$, respectively. The thiobarbituric acid value of oils heated for different times was decreased by different PACFs. The oils heated for 16 and $20 \mathrm{~h}$ and treated with 5\% DPACFs and GPACFs were the best results in this study.

\section{AUTHOR CONTRIBUTIONS}

Han Chien LIN designed this study and wrote the paper. Miao-Han Yang performed the experiments, analyzed the data and the statistical analysis. Noboru FUJIMOTO participated in the design of the study and supervised the works. All authors assisted in editing of the manuscript and approved the final version.

\section{REFERENCES}

Ames, B. N. 1975 Methods for detecting carcinogens and mutagens with the Salmonella/mammalian-microsome mutagenicity test. Mutate Res, 31: 347-364

Al-Harbi, M. M. and H. A. Al-Kahtani 1993 Chemical and biological evaluation of discarded frying palm oil from commercial restaurants. Food Chemistry, 48(4): 395-401

Amuda, O. S., A. A. Giwa and I. A. Bello 2007 Removal of heavy metal from industrial wastewater using modified activated coconut shell carbon. Biochemical engineering journal, $\mathbf{3 6}(2)$ : 174-181

Asakura, R., M. Morita, K. Maruyama, H. Hatori and Y. Yamada 2004 Preparation of fibrous activated carbons from wood fiber. Journal of Materials Science, 39: 201-206

Aworn, A., P. Thiravetyan and W. Nakbanpote 2008 Preparation and characteristics of agricultural waste activated carbon by physical activation having micro- and mesopores. J. of Anal. Appl. Pyrol., 82(2): 279-285

J ANAL APPL PYROL

Bennion, M. and F. Hanning 1956 Effect of different fats and oils and their modification on changes during frying. Food Technology, 10(5): 229-232

Bivainis, V. and V. Jankauskas 2015 Impact of corrugated paperboard structure on puncture resistance. Materials Science, 21(1): 37-61

Boatella-Riera, J., R. Codony, M. Rafecas and F. Guardioal 2000 Recycled cooking oils: Assessments of risk for public health. European Parliament PE, p. 289

Boki, K., T. Wada and S. Ohno 1991 Effects of filtration through activated carbons on peroxide, thiobarbituric acid and carbonyl values of autoxidized soybean oil. J. Am. Oil. Chem. Soc., 68(8): $561-565$

Bracco, U., A. Dieffenbacher and L. Kolarovic 1981 Frying performance of palm oil liquid fractions. J. Am. Oil. Chem. Soc., 58(1): $6-12$

Buck, D. F. 1981 Antioxidants in soya oil. J. Am. Oil. Chem. Soc., 58(3 Part 2): 275-278

Brunaver, S. 1943 The adsorption of gasses and vapor Vol. 1. physical adsorption prinception. University, Prinception, New York.

Choe, E. and D. B. Min 2006 Mechanisms and factors for edible oil oxidation. CRFSFS, $\mathbf{5}(4)$ : 169-186

Chugh, B., and K. Dhawan 2014 Storage studies on mustard oil blends. J. Food Sci. Technol., 51(4): 762-767

Del Rio, D., A. J. Stewart and N. Pellegrini 2005 A review of recent studies on malondialdehyde as toxic molecule and biological marker of oxidative stress. Nutr Metab Cardiovasc Dis., 15(4): 316-328

Ellis, R. L. and K. M. Sedlachek 1993 Recycled versus virginfiber characteristics: A comparison. Secondary fiber recycling, pp. 7-19

Frega, N., M. Mozzon and G. Lercker 1999 Effects of free fatty acids on oxidative stability of vegetable oil. J. Am. Oil. Chem. Soc., $\mathbf{7 6}(3)$ : 325-329

Fritsch, C. W. 1981 Measurements of frying fat deterioration: a brief review. J. Am. Oil. Chem. Soc., 58(3): 272-274

Gregg, S. J. and K. S. W. Sing 1982 The physical adsorption of gases by nonporous solids: The type II isotherm. Adsorption, surface area and porosity. Academic Press, London. pp. 41-110

Gutierrez, R., O. Gonzalez and M. C. Dobarganes 1988 Analytical procedures for the evaluation of used frying fats. Frying Food: Principles. Changes, New Approaches, London, UK: VCH Publishers Ltd, pp. 141-154

Hu, Z. and M. P. Srinivasan 1999 Preparation of high-surfacearea activated carbons from coconut shell. Micro. Meso. Mat. 27: 11-18

Huang, A. S., O. A. L. Hsieh, C. L. Huang and S. S. Chang 1981 A comparison of the stability of sunflower oil and corn oil. J. Am. Oil. Chem. Soc., 58(11): 997-1001

Huang, W. J., M. H. Duh and H. C. Lin 2010 Investigation of absorption properties of activated carbon fibers prepared from Nadelholz/Laubholz Pulp. J Agric. For., 7(1): 16-31

Iqbal, S. and M. I. Bhanger 2007 Stabilization of sunflower oil by garlic extract during accelerated storage. Food Chemistry, 100(1): 246-254

Jain, M. R., R. Sawant, R. D. A. Paulmer, D. Ganguli and G. Vasudev 2005 Evaluation of thermo-oxidative characteristics of gear oils by different techniques: Effect of antioxidant chemistry. Thermochimica acta, $\mathbf{4 3 5}$ (2): 172-175

Kanner, J., S. Gorelik, S. Roman and R. Kohen 2012 Protection by polyphenols of postprandial human plasma and low-density lipoprotein modification: the stomach as a bioreactor. J. Am. Oil. Chem. Soc., 60(36): 8790-8796

Keijbets, M. J. H., G. Ebbenhorst-Seller and J. Ruisch 1985 Suitability of hydrogenated soybean oils for prefrying of deepfrozen french fries. J. Am. Oil. Chem. Soc., 62(4): 720-724

Kim, J. W., M. H. Sohn, D. S. Kim, S. M. Sohn and Y. S. Kwon 2001 Production of granular activated carbon from waste walnut shell and its adsorption characteristics for $\mathrm{Cu}^{2+}$ ion. J. Hazard. Mater., 85(3): 301-315

Läubli, M. W. and P. A. Bruttel 1986 Determination of the oxidative stability of fats and oils: Comparison between the active oxygen method (AOCS Cd 12-57) and the rancimat method. J. Am. Oil. Chem. Soc., 63(6): 792-795

Lin, H. C., Y. C. Weng, G. S. Hwang and N. Fujimoto 2014a Adsorption and preliminary safety evaluation of activated carbons refined from charcoals. J. Fa.c Agr., Kyushu Univ., $\mathbf{5 9}(1): 117-125$

Lin, H. C., L. Y. Tseng, Y. J. Lai, S. C. Wu and N. Fujimoto 2014 b Biological safety assessment of functional activated carbons pre- 
pared from three agricultural wastes. J. Fa.c Agr., Kyushu Univ., 59(2): 321-331

Lin, H. C., J. F. Liou, W. J. Lee, S. C. Wu, M. H. Duh and N. Fujimoto 2015a Development of environmental protection wood-based activated carbon fibers paperboard and its application in hygroscopic ability. J. Fac. Agr., Kyushu Univ., 60(1): 163-171

Lin, H. C., J. C. Hsueh, J. Lee, Y. J. Lai, S. C. Wu and N. Fujimoto $2015 \mathrm{~b}$ Safety evaluation of wood-based activated carbon fibers in a 28-day feeding study in sprague-dawley rats. J. Fac. Agr., Kyushu Univ., 60(2): 427-434

Lin, S., C. C. Akon and A. E. Reynolds 1998 The recovery of used frying oils with various adsorbents. Journal of Food Lipids, 5(1): $1-16$

Lumley, I. D. 1988 Polar compounds in heated oils. Frying of Food: Principles. Changes, New Approaches" (Eds.): Varela, G., Bender, AE and Morton, ID. Ellis Horwood Ltd., Chichester. pp. $166-173$

Marnett, L. J. 1999 Lipid peroxidation-DNA damage by malondialdehyde. Mutat Res., 424(1-2): 83-95

Okada, K., N. Yamamoto, Y. Kameshima and A. Yasumori 2003 Porous properties of activated carbons from waste newspaper prepared by chemical and physical activation. J COLLOID INTERF SCI., 262(1): 179-193

Paul, S., G. S. Mittal and M. S. Chinnan 1997 Regulating the use of degraded oil/fat in deep-fat/oil food frying. Crit. Rev. Food Sci. Nutr., 37(7): 635-662

Peng, C. W., Y. N. Wang, J. H. Lu, M. J. Chung and H. C. Lin 2012 Preparation of Japanese cedar activated carbon by combining activation with white popinac (Leucaena leucocephala) ash and steam. J. Exp. For. Nat. Taiwan Univ., 26(2): 33-48

Proctor, A. and R. Gnanasambandam 1997 Soy hull carbon as adsorbents of crude soy oil components: Effect of carbonization time. J. Am. Oil. Chem. Soc., 74(12): 1549-1552

Stevenson, S. G., M. Vaisey-Genser and N. A. M. Eskin 1984 Quality control in the use of deep frying oils. J. Am. Oil. Chem. Soc., 61(6): 1102-1108
Sun, S, J. H. Schiller and A. F. Gazdar 2007 Lung cancer in never smokers-a different disease. Nat Rev Cancer, 7(10): 778-790

Teng, H., and L. Y. Hsu 1999 High-porosity carbons prepared from bituminous coal with potassium hydroxide activation. IND ENG CHEM RES, 38(8): 2947-2953

Tseng, L. Y., S. C. Wu and H. C. Lin 2007 Mutagenic evaluation and physical absorption properties of corn Cob, bagasse pith and mushroom stalk activated carbon. J. Agric. For., 4(2): $1-17$

Wu, W. L., S. C. Wu and H. C. Lin 2010 Investigation on water activity and absorption properties of activated carbons prepared from agricultural wastes using methods of physical activation with $\mathrm{CO}_{2}$ and steam. J. Agric. For., 7(1): 1-15

Yates, R. A., and J. D. Caldwell 1993 Regeneration of oils used for deep frying: a comparison of active filter aids. J. Am. Oil. Chem. Soc., 70(5): 507-511

Zhang, T., W. P. Walawender, L. T. Fan, M. Fan, D. Daugaard and R. C. Brown 2004 Preparation of activated carbon from forest and agricultural residues through $\mathrm{CO}_{2}$ activation. Chem. Eng., 105: $53-59$

Ziaiifar, A. M., N. Achir, F. Courtois, I. Trezzani, and G. Trystram 2008 Review of mechanisms, conditions, and factors involved in the oil uptake phenomenon during the deep-fat frying process. IJFST, 43(8): 1410-1423

Environmental Protection Administration 2018 Recycling Fund Management Board. Environmental Protection Administration (EPA), Executive Yuan, Taiwan ROC. https://reurl.cc/N9Dam. $11^{\text {th }}$ Nov., 2018

Ministry of Health and Welfare 2009 The Frying oil replacement standard. Ministry of Health and Welfare, Executive Yuan, Taiwan ROC. https://www.fda.gov.tw/TC/sitecontent. aspx?sid=2707. $6^{\text {th }}$ July, 2019

Ministry of Health and Welfare 2010 The Food nutrient database. Ministry of Health and Welfare, Executive Yuan, Taiwan ROC. https://consumer.fda.gov.tw/Food/TFND.aspx?nodeID $=178.9^{\text {th }}$ Oct., 2019 